\title{
The Subantarctic Front as a sedimentary conveyor belt for
}

\section{tsunamigenic submarine landslides}

Uisdean Nicholson $^{1 *}$, Simon Libby ${ }^{1}$, David R Tappin ${ }^{2,4}$, Dave McCarthy ${ }^{3}$

${ }^{1}$ Institute of Petroleum Engineering, School of Energy, Geoscience, Infrastructure and Society, Heriot-Watt University, Edinburgh EH14 4AS, Scotland, UK.

${ }^{2}$ British Geological Survey, Keyworth, NG12 5GG, Nottingham, UK

${ }^{3}$ British Geological Survey, Lyell Centre, Edinburgh, EH14 4AP

${ }^{4}$ Department of Earth Sciences, University College, London, WC1E 6BT, UK *corresponding author email address: u.nicholson@hw.ac.uk

The Subantarctic Front (SAF), one of the three main jets of the Antarctic Circumpolar Current (ACC), flows through a narrow gap in the North Scotia Ridge and then northwestward across the continental slope of Burdwood Bank, $\sim 150 \mathrm{~km}$ south of the Falkland Islands. There, the SAF flows across a fold-and-thrust belt caused by oblique convergence at the active plate boundary between the Scotia Plate and South American Plate. We here use regional $2 \mathrm{D}$ and $3 \mathrm{D}$ seismic reflection data to show the interaction of the associated bottom currents with the active margin, particularly to understand the causes and consequences of a number of large submarine landslides located in the adjacent foredeep. Kinematic indicators from the landslide deposits show that they are derived from a single point source located in an embayment on the northern slope of Burdwood Bank, where we identify a large contourite drift deposit. This drift forms the depositional sink for an alongslope sediment routing system driven by currents associated with the SAF, with sediment 
being eroded from the Burdwood Terrace, transported $\sim 200 \mathrm{~km}$ westward, and plastered against the middle-upper continental slope. The contourite drift is undercut by the core of the current, making the slope inherently unstable in this area. Numerical modelling of the landslides and resultant waves indicates the tsunamigenic potential of these events. Modelled peak wave elevations of up to $40 \mathrm{~m}$ inundate the southern coast of the Falklands for a $\sim 100 \mathrm{~km}^{3}$ volume landslide, with a recurrence interval of $1 \mathrm{Ma}$ or less. This research highlights preconditioning mechanisms for submarine failure on continental slopes dominated by strong ocean currents, and specifically, oceanographic controls on the frequency, magnitude and location of submarine landslides associated with contourite systems.

Keywords: submarine landslide; tsunami; contourite; Antarctic Circumpolar Current;

\section{Introduction}

The majority of recent catastrophic tsunamis, such as those in the Indian Ocean (2004) and Japan (2011), have been triggered by megathrust earthquakes, typically exceeding $M_{w} 8.5$ (Ward, 2001, Blewitt et al., 2006), so research on tsunami hazard has primarily focused on active subduction zones (Satake and Atwater, 2007). In the last two decades, however, there has been an increasing recognition of the tsunami hazard from submarine landslides, many of which are associated with moderate magnitude, $\mathrm{M}_{\mathrm{w}}$ 6-8 earthquakes (Hornbach et al., 2010, Tappin et al., 1999, Harbitz et al., 2006, Tappin et al., 2014). More recent tsunami events, such as the $\mathrm{M}_{\mathrm{w}} 7.5$ Sulawesi earthquake of September 2018 (Heidarzadeh et al., 2019) and $M_{w} 7.0$ Haiti earthquake (Hornbach et al., 2010) highlight the potential hazard of smaller magnitude strike-slip 
earthquakes with associated submarine landslides, although the precise tsunami mechanisms are still controversial. The recognition of tsunami generation from submarine landslides is in part due to the increasing resolution and spatial coverage of multibeam echosounding bathymetry (MBES) and the increasing availability of petroleum industry multichannel seismic (MCS) reflection data. The spatial coverage of this data has contributed to the recognition of submarine landslides as a common feature of continental margins worldwide (Moscardelli and Wood, 2016). Although most landslides do not generate ocean-wide (far field) tsunamis because of their small volume and tsunami wave frequency dispersion (Masson et al., 2006), they represent a significant hazard because of their elevated and focused run-ups near their source locations (Harbitz et al., 2006). These can cause significant damage and loss of life (e.g. the 1998 Papua New Guinea tsunami with $>2200$ casualties) (Tappin et al., 1999). In addition, some prehistoric, large-volume $\left(>1000 \mathrm{~km}^{3}\right)$ submarine landslides, such as Storegga $(8,200 \mathrm{BP})$, have generated ocean-wide tsunamis, with run-up heights of $>20-30 \mathrm{~m}$ (e.g. Storegga slide) (Bondevik et al., 2003), which are comparable in elevation to the 2004 Indian Ocean, earthquake-generated tsunami (Geist et al., 2007).

Although earthquakes are the most common trigger of submarine landslides, certain preexisting physical and sedimentological conditions can prime continental margin sediments for failure. These conditions include sediment-loading or over-steepening of continental slopes (Assier-Rzadkieaicz et al., 2000), buildup of overpressures in slope sediments (Prior and Coleman, 1982), the presence of weak, slope-parallel sediment layers (O'Leary, 1991) and, more controversially, gas-hydrate dissociation resulting from sea-level change (Sultan et al., 2004). The most well-documented pre-historic submarine landslide is the Storegga Slide offshore of Norway, which was likely to have been pre-conditioned by weak, fine-grained contourite 
deposits underlying coarse-grained glacigenic deposits (Bryn et al., 2005). The rapid deposition of the glacigenic deposits led to overpressure in the contourites, leading to their failure from earthquake triggering during the Early Holocene (Bryn et al., 2005, Kvalstad et al., 2005, Solheim et al., 2005). Thus, deposition of mechanically weak contourite sediment by along-slope currents can be an important control on generating large-volume submarine landslides.

We here document a number of large volume $\left(\sim 100 \mathrm{~km}^{3}\right)$ to giant $\left(\sim 1000 \mathrm{~km}^{3}\right)$ mass transport deposits (MTDs), the depositional products of submarine landslides caused by slope failure, in the South Atlantic along the northern margin of Burdwood Bank, on the South American-Scotia plate boundary (Figure 1). From landslide morphology and kinematic indicators on the MTDs, we identify the source and preconditioning mechanisms of these landslides. In the absence of an obvious sediment source for these deposits, we examine the role of active bottom currents associated with the Subantarctic Front (SAF), and we test the hypothesis that the landslides are both supplied by, and preconditioned by, strong bottom currents in the region. Finally, we use our observations from the MTDs as the basis of numerical tsunami landslide modelling, from which we determine their potential hazard for coastal communities in the region.

\section{Tectonic and oceanographic setting}

The North Scotia Ridge (NSR) forms part of a submerged, oblique-compressional plate boundary between the South American Plate to the north and the Scotia Plate to the south (Figure 1). The boundary is seismically active, with both strike-slip and compressional earthquakes up to $\mathrm{M}_{\mathrm{w}}$ 7.0. The exact plate-boundary configuration remains uncertain, with some models proposing oblique convergence along a continuous fault situated in the Falkland Trough (Pelayo and 
Wiens, 1989, Bird, 2003), and others proposing partitioned strain with parallel compressional and strike-slip segments (Lagabrielle et al., 2009). Epicentres of recent earthquakes are clustered in discrete locations, which may be aligned along segments of the plate boundary. The largest events, situated between the east of Burdwood Bank and Davis Bank, have predominantly leftlateral focal mechanisms, although there is also a diffuse cluster of $M_{w} 4-6$ events along the northern margin of Burdwood Bank (Figure 1C).

The NSR itself consists of a series of microcontinents which rifted from a contiguous Patagonia-Antarctica arc during the Paleogene, and collided with the southern margin of the Falkland Plateau during the Eocene (Galeazzi, 1998, Bry et al., 2004). Since the Eocene, the margin has undergone a combination of compression and left-lateral strike-slip deformation (Eagles et al., 2005) although the amount of lateral translation of the eastern component of the NSR (including South Georgia) remains controversial (Eagles and Jokat, 2014). Compression, with associated crustal loading at the plate boundary, resulted in the formation of an east-westtrending foreland basin, the South Falkland Basin (Bry et al., 2004), where up to $7 \mathrm{~km}$ of sediment was deposited during formation (Baristeas et al., 2013). The basin is still active and now forms the bathymetric feature termed the Falkland Trough, where water depths increase from approximately $500 \mathrm{~m}$ in the west to more than $5000 \mathrm{~m}$ in the east, north of Davis Bank (Figure 1).

The Subantarctic Front (SAF) is one of the main jets of the Antarctic Circumpolar Current (ACC), the world's largest moving body of water, which continuously transports 134 Sverdrups (Sv) of water around Antarctica (Figure 1A) (Smith et al., 2010). The ACC is driven by surface shear stress caused by the South Westerly Winds. In the absence of any continental barriers to deflect or modify the ACC, the shear stresses are transmitted to the deep ocean. The 
majority of water masses associated with the ACC are transported by relatively narrow, vertically aligned jets which extend from the sea surface to the seabed (Figure 1B). Of these jets, the SAF alone is responsible for transporting around 48 Sverdrups (Sv) of water through the narrow 54-54 passage in the NSR. From there, the SAF flows across the northern slope of Burdwood Bank until it converges with the subducting Subantarctic Mode Water, which flows across the saddle between Tierra del Fuego and Burdwood Bank and then eastward into the Falkland Trough (Piola and Gordon, 1989). From this convergence zone, the current flows northward across the Falkland Plateau into the South Atlantic. Velocities at the core of the SAF exceed $50 \mathrm{~cm} / \mathrm{s}$ near the sea surface, and $20-30 \mathrm{~cm} / \mathrm{s}$ near the seabed at $\sim 1500 \mathrm{~m}$ water depth, based on a limited number of velocity transects across the Falkland Plateau (Smith et al., 2010) and Scotia Ridge (Naveira Garabato et al., 2003). In the absence of other datasets in the region, however, these transects represent temporal snapshots of what are likely to be ambient conditions. Based on multi-year observations of ACC dynamics in the Drake Passage, bottom current velocities associated with the SAF show significant seasonal variations, and reach velocities of up to $70 \mathrm{~cm} / \mathrm{s}$ where there are mesoscale eddies (Chereskin et al., 2012). Highresolution numerical models for the Falkland Plateau also highlight the presence and importance of these eddies, particularly where the SAF interacts with the shallower sea bed of the North Scotia Ridge around the 54-54 Passage (Hallberg and Gnanadesikan, 2006).

The SAF was initiated at, or very close to, the Eocene-Oligocene boundary, as evidenced by widespread erosion of the continental slope, and deposition of extensive contourite sands of early Oligocene age on the Falkland Plateau (Nicholson and Stow, 2019). These show that at this time both the Drake Passage and 54-54 Passage were already sufficiently deep to allow the formation of the ACC. Current velocities associated with the SAF were sufficient to erode the 
Falkland Plateau to a depth of $>300 \mathrm{~m}$. The most pronounced erosion has taken place at water depths of 1200-1800 m, resulting in the formation of a broad erosional terrace (the Falkland Terrace). Deposition of discrete sediment drifts associated with the SAF was much more recent, with sediment accumulating in the South Falkland Slope Drift (SFSD) since the Early Pliocene (Weber, 2019). The late onset of drift deposition relative to the timing of initiation of the ACC suggests a decrease in current intensity, or a narrower, more constrained SAF since the Pliocene (Nicholson and Stow, 2019). The impact of these currents on the continental slope of the Burdwood Bank, north and east of the 54-54 Passage, and including the fold-and-thrust belt at the Scotia-South America plate boundary, has not previously been documented.

\section{Data and methods}

\section{1. $\quad$ Seismic and well data}

We use a regional dataset of $>35,000$ line $\mathrm{km} 2 \mathrm{D}$ multichannel seismic and two large (total of $\sim 3,600 \mathrm{~km}^{2}$ ) 3D seismic reflection volumes, the FIST and BSP surveys. The 2D data were acquired and processed by a number of different operators between 1978 and 2007. Record lengths for all surveys are between 8-10 seconds, with sampling intervals of 2-4 ms. All surveys were processed using standard industry processing techniques, including multiple elimination, NMO correction, and full Kirchhoff pre-stack time migration to restore the position of the reflectors in the time domain. Despite this processing sequence, seabed and subsurface multiples remain in many of the $2 \mathrm{D}$ seismic lines.

The 3D surveys were acquired and processed by PGS. The sound source was two Bolt LLXT airguns with an air pressure of 2000 psi and 4130 cubic inch volume. Data were recorded using an array of $12 * 6.6 \mathrm{~km}$ long streamers at $120 \mathrm{~m}$ spacing, each with 528 Hydroscience 24 bit 
hydrophones at a $12.5 \mathrm{~m}$ group interval, with a horizontal resolution of $12.5 \mathrm{~m}$. The FIST survey was processed using a 3D Kirchhoff pre-stack time migration (PSTM) sequence. The BSP survey was processed using a pre-stack depth migration (PSDM) sequence, with final stacked volumes in both depth and time.

Seismic interpretation was carried out using Schlumberger Petrel 2015 software, including horizon mapping, dip and amplitude extractions for seismic geomorphological analyses. The tops and bases of the three largest MTDs were mapped in detail on 2D and 3D seismic data, with tops corresponding to strong 'hard' (downward increase in acoustic impedance) and bases as strong 'soft' reflections. Kinematic indicators were identified from attribute maps of these horizons, particularly flow-parallel lineations at the basal shear surfaces of the deposits, as well as internal imbrication.

Lithological, petrophysical and biostratigraphic data from two exploration boreholes (Darwin-1 and Stebbing-1; Fig. 1) are used to calibrate the stratigraphic age and lithology of seismic reflections. The Stebbing-1 well was drilled in the fold-and-thrust belt north of Burdwood Bank at a water depth of $1593 \mathrm{~m}$ below mean sea level. The shallowest stratigraphic section was drilled without a riser, with no samples recovered to surface. Samples were recovered from a depth of $2140 \mathrm{~m}$ (measured depth, MD) to the bottom of the well (TD) at 3060 m MD. The Darwin-1 well was drilled in the foreland basin, at a water depth of $2011 \mathrm{~m}$. Sample recovery in the well is from a depth of $3035 \mathrm{~m}$ to the bottom of the well at $4876 \mathrm{~m} \mathrm{MD}$.

Although there are no well samples at the shallow depths of the submarine landslides and contourite drifts, biostratigraphic data from deeper well sections, combined with regional correlation to the Malvinas Basin and South Falkland Slope Drift, allow us to constrain the age of seismic reflections underlying the submarine landslides, so allowing us to estimate the 
frequency of these events. For the MTDs, sonic logs from Darwin-1 were used to convert TWT of top and base reflectors into depth, so thickness and sediment volumes could be reconstructed.

The seismic and well data are available on request from the Falkland Island Government (http://www.fig.gov.fk/minerals/).

\subsection{Tsunami generation and propagation}

Submarine landslide and initial tsunami wave formation were modelled using the 3D non-hydrostatic model NHWave (Ma et al., 2012). This model has been validated for highly dispersive landslides and resultant tsunamis by comparing wave elevations to laboratory experiments (Enet and Grilli, 2007). Landslides for our base case model were simulated by reconstructing $100 \mathrm{~km}^{3}$ of sediment volume, distributed in a quasi-Gaussian elliptical geometry onto the continental slope (between 280 to $1340 \mathrm{~m}$ ) of the embayment identified as the point of origin for all of the submarine landslides in the South Falkland Basin. The reconstructed sediment body has an along-slope width of $50 \mathrm{~km}$, down-slope length of $20 \mathrm{~km}$ and a maximum thickness of $300 \mathrm{~m}$ (Figure $8 \mathrm{~B}$ ). The initial acceleration for this model is $0.37 \mathrm{~m} / \mathrm{s}^{2}$ based on calibrated values from offshore Japan (Tappin et al., 2014), where both slope angle and morphology are similar and modelled parameters were validated with maximum wave heights and runup onshore. Nevertheless, the initial acceleration, which is almost impossible to measure empirically, remains a source of significant uncertainty in such models. Based on Japan (Tappin et al., 2014), a maximum landslide velocity of $30 \mathrm{~m} / \mathrm{s}$ was used, comparable with the maximum velocities from the Grand Banks landslide, which resulted in the 1929 Newfoundland tsunami (Fine et al., 2005). Multiple iterations of the model were run with different sediment volumes, water depth at slide initiation, initial acceleration, maximum velocity and angle of slope. Of 
these conditions, water depth and initial acceleration were the most sensitive in terms of model outputs.

Following the initial wave generation (Figure 8D-F) in NHWave, the fully nonlinear Boussinesq model FUNWAVE-TVD (Shi et al., 2012, Kirby et al., 2013) was used to simulate wave propagation and run-up. FUNWAVE-TVD uses a 'Total Variation Diminishing (TVD) algorithm that accurately simulates wave-breaking dissipation and inundation, and has been extensively validated and calibrated using laboratory studies and field benchmarks (Tehranirad et al., 2011).

\section{Results}

\subsection{Slope morphology of the South America - Scotia plate boundary}

Along the northern margin of Burdwood Bank, the structure of the South America-Scotia plate boundary and the continental slope varies significantly, with elements of both strike-slip and compressional deformation (Figure 2). We subdivide the northern margin of the bank into three segments, each with a distinct morphology and structural characteristics. The slope of the northwestern Bank (segment 1 ), between $61^{\circ} \mathrm{W}$ and $59.5^{\circ} \mathrm{W}$, strikes WNW-ESE with a relatively shallow dip $\left(2-4^{\circ}\right)$ (Figure $\left.2 \mathrm{~B}\right)$. On the upper slope, extending towards the northwest, there are prominent sediment waves, with amplitudes of up to $100 \mathrm{~m}$. Because of seabed and subsurface multiples, seismic data on the upper slope is low resolution, so deeper structures are obscured. The central margin (segment 2) of the Bank between $59.5^{\circ} \mathrm{W}$ and $58.5^{\circ} \mathrm{W}$, strikes WSW-ENE and is characterized by a steep $\left(\sim 12^{\circ}\right)$ upper slope, a locally convex-up middle slope $\left(\sim 4-8^{\circ}\right)$, and a gently dipping lower slope $\left(<2^{\circ}\right)$ (Figure $2 \mathrm{C}$ ). Here the Bank is underlain by a faulted and folded sequence, which we interpret as a 'positive flower structure'. This flower structure has 
little or no bathymetric expression, and is likely caused by a deep-seated, sub-vertical strike-slip fault, which we consider to be a major control on the overall geometry of the Burdwood Bank margin. There is a pronounced bottom-simulating reflector (BSR) in this region (Figure 2C). Because of its reverse polarity (relative to the seabed), shallow depth below the seabed (several hundred metres at water depths greater than 500-600 m), and the presence of underlying, high amplitude reflections we interpret the BSR as the base of the gas hydrate stability zone.

The northeastern margin of Burdwood Bank (segment 3 on Figure 2A) extends from $58.5^{\circ} \mathrm{W}$ to $56^{\circ} \mathrm{W}$, beyond the eastward limit of our seismic data, and strikes WNW-ESE. The slope morphology is distinctly different to the western and central margin. The upper slope is relatively gently dipping $\left(\sim 2-3^{\circ}\right)$ (Figure $\left.2 \mathrm{D}\right)$. There is a highly deformed mid-slope terrace, which is separated from the lower slope fold-and-thrust belt by a deeply incised, slope-parallel valley, which we interpret as an erosional moat. The planform morphology of the structures within the fold-and-thrust belt at this location show that the structures strike WNW-ESE. We refer to the prominent and extensive mid-slope terrace as the Burdwood Terrace.

The structural configuration of the northern margin of Burdwood Bank evidently has a significant control on slope orientation and steepness. The WSW-ENE slope segment 2 parallels the left-lateral focal mechanisms of many of the large earthquakes (Figure 1C), and may be parallel to a strike-slip component of the plate boundary. The WNW-ESE slope segments ( 1 and 3) and the strike of the structures within the fold-and-thrust belt are oriented at around $30^{\circ}$ to this, so may be in a transpressional configuration. The structural domains also have a major influence on sedimentation and remobilization at the plate boundary. In particular, the slope gradient, together with large slope embayments at the boundary between structural domains creates accommodation space for potential sediment accumulation along the slope. 


\subsection{Stratigraphy of the South Falkland Basin}

The stratigraphy of the South Falkland Basin is constrained by two recent (2012) exploration wells, Stebbing-1 and Darwin-1 (Figures 2 and 3), as well as by correlation with the South Falkland Slope Drift to the north and the Malvinas Basin, $\sim 300 \mathrm{~km}$ north-west of Burdwood Bank (Figure 4). We focus here on the latest Eocene-Recent stratigraphic sequence, deposited in the foreland basin after the collision of Burdwood Bank (Bry et al., 2004).

The Stebbing-1 well was drilled on a toe-thrust anticline within the fold-and-thrust belt north of Burdwood Bank (Figure 2E). From 2140-2310 m, the well encountered deepwater latest Oligocene - earliest Miocene clastic sediments, with a substantial amount of reworked, predominantly Eocene, material. At 2011-2237 m, the well encountered two thick debrites, or MTDs, of latest Oligocene to earliest Miocene age, which thicken substantially to the west (Figure 3). We refer to these deposits collectively as the Burdwood Slide (Figure 3). The well then encountered deepwater Oligocene sediments, predominantly reworked from the Eocene, until a depth of $3055 \mathrm{~m}$. Below an unconformity at $3055 \mathrm{~m}$, the well encountered $\sim 5 \mathrm{~m}$ of middle Eocene (Bartonian-Lutetian, giving a possible age range of 37-49 Ma) sediments with no significant evidence for reworking. This unconformity, which represents at least 4 Ma of missing section, coincides with a clear change in seismic facies, from continuous low-amplitude reflections above to moderate-amplitude, semi-continuous reflections below (Figure 2C, foreland unconformity). Based on seismic stratigraphic evidence and correlation with the Malvinas Basin, we interpret this middle Eocene-Oligocene unconformity as the base of the foreland basin sequence. 
The Darwin-1 well was drilled in the active foreland basin, targeting a Cretaceous tilted fault block in the underthrust Falkland Plateau (Figure 3). From 3035-3365 m, the sediments consist of deepwater clastics of Middle to Early Miocene age, although there is some uncertainty over the exact age due to the high proportion of reworked Eocene fossils. Notwithstanding, the dating does constrain the age of the seismic reflections, with the pink horizon (Figure 3) no younger than Middle Miocene in age. Below $3365 \mathrm{~m}$, the well encountered a thick sequence of neritic Cretaceous (Campanian-Barremian) sediments, deposited on a passive margin before the collision with Burdwood Bank. The foreland unconformity (orange horizon) thus represents a sedimentary hiatus of at least $50 \mathrm{Ma}$ at this location.

In addition to the wells described above from the South Falkland Basin, numerous exploration wells have been drilled in the Malvinas Basin. These provide a robust stratigraphic framework for the Malvinas Basin (Galeazzi, 1998, Baristeas et al., 2013) and an additional means of stratigraphic calibration for our seismic in the South Falkland Basin (Figure 4). The foreland basin unconformity in the Malvinas Basin is dated at $42.5 \mathrm{Ma}$, which is consistent with our interpretation of Stebbing-1. As a prominent erosional unconformity, this event is easy to correlate between the two basins despite the presence of an intervening basin high. The shallowest seismic horizon to be calibrated by Malvinas wells is the ' $5.5 \mathrm{Ma}$ ' horizon (Baristeas et al., 2013). We note that some uncertainty remains ( $\pm 200 \mathrm{~ms}$ in the central South Falkland Basin) for the correlation of this horizon because of poor seismic data quality.

We also correlate an additional seismic reflector, 'Horizon P', between the two basins. Horizon $\mathrm{P}$ is a prominent continuous negative reflection (a downward decrease in acoustic impedance) that can be confidently interpreted from a near seabed position in the Malvinas Basin to approximately 1s TWT (around $1 \mathrm{~km}$ depth) below the seabed in the South Falkland Basin. 
Horizon P is stratigraphically shallower and thus clearly younger than the 5.5 Ma horizon. Horizon P represents a significant transition in seismic facies in the foreland basin succession of the South Falkland Basin. It separates a sequence below of relatively continuous high-amplitude reflections and minor thin, chaotic units from a sequence above dominated by thick (up to 200 ms) chaotic units (Figures 3 and 5). The chaotic units are interpreted as laterally extensive MTDs, the depositional products of large-volume submarine landslides.

Horizon P also onlaps the SFSD in the western Falkland Trough (Figure 2C, 4B), including both the 1A and lower part of the 1B seismic sequences (Koenitz et al., 2008) (Figure 4B). Based on ages obtained from the recent IODP U-1534 well in the SFSD (Weber, 2019), the 1B seismic stratigraphic sequence is Late Pliocene (2.6-3 Ma) in age. This provides a maximum age (3 Ma) for Horizon P. Koenitz et al. (2008) interpret the whole sequence above Horizon P in the Falkland Trough at this location to be equivalent in age to their 2A sequence, which is tentatively dated as being $\sim 0.1-0.78 \mathrm{Ma}$ (Weber, 2019). However, they assumed a much older (Early Miocene) age for the SFSD, which likely influenced their correlation. We note that the unconformity separating the $1 \mathrm{~B}$ and $2 \mathrm{~A}$ sequence is not seismically correlatable based on the existing data, and may not be the same age as the unconformity which forms the onlap surface between the Falkland Trough fill and the SFSD (Figure 4B). We therefore consider an age of 0.78 Ma to be unlikely, but a possible minimum age for Horizon P.

\subsection{Submarine landslides in the South Falkland Basin}

The three largest MTDs, (1, 2 and 3) in the South Falkland Basin were mapped across the 3D and 2D seismic data (Figure 2 and 5). From their internal character and seismic resolution, the MTDs are clearly individual events, with well-defined top and base reflections. They have 
deeply incised bases, cutting down as much as $100 \mathrm{~ms}(\sim 100 \mathrm{~m})$ into the underlying substrate (Figure 5A), and rugose tops, which represent individual clasts or blocks, some of which exceed $1 \mathrm{~km}$ in diameter (Figure 5D). Basal erosion is highly variable, but greatest at the western margin of the basin. In the case of MTD 2, a deeply scoured, circular feature $\sim 200 \mathrm{~km}^{2}$ is located immediately north of a north-south trending incised valley of the same age, which extends to the south of the 3D survey area (Figure 5B). The kinematic indicators on the basal shear surface show that the initial flow was to the NNE in the incised valley, and then the landslide turned eastward along the axis of the foredeep of the Falkland Trough at the base of the slope (Figure 5C). Velocities were likely at their maximum where the deeply incised scour is located, at the change in slope immediately in front of the landslide. The geometry of the scour, together with the kinematic indicators, suggest that the landslide had a significant $(>15 \mathrm{~km}$ from the axis of the foredeep) run-up onto the northern basin margin, before reversing and flowing back into the foredeep to the east. These observations show that the landslide originated from a discrete location on the northern margin of Burdwood Bank, at around $59.5^{\circ} \mathrm{W}$, where there is a broad embayment on the steep, strike-slip segment of the margin (Figure 2). Kinematic indicators and thickness maps (Figure 5B) of the other MTDs show that these all originated from the same central margin segment on the northern slope of Burdwood Bank as MTD 2.

Sediment volumes of the MTDs, derived from depth-converted sediment thickness maps, all exceed $>89 \mathrm{~km}^{3}$. Because the MTDs all extend eastward of the seismic data, these volumes are regarded as minimum values for the original landslides. Based on a maximum age of $3 \mathrm{Ma}$ for Horizon P, the maximum recurrence interval of the submarine landslides that form the large volume $\left(\sim 100 \mathrm{~km}^{3}\right)$ MTDs is $1 \mathrm{Ma}$. There is also seismic evidence for multiple smaller, more frequent, events (Figure 5D). 
There are also a number of other MTDs in the older sequence, which are significantly larger than MTDs 1-3. Two of these, which we refer to collectively as the 'Burdwood Slide' (BS), have a cumulative mapped volume of $\sim 950 \mathrm{~km}^{3}$. This volume represents two separate events, but a significant component of each of the constituent MTDs it has been entrained in the highly deformed fold-and-thrust belt to the south of our seismic coverage, so the original volume of each MTD is likely significantly larger. These are constrained by the Stebbing-1 well as being latest Oligocene to Early Miocene in age. Assuming that the Late Oligocene - Early Miocene foreland basin had a similar width to that of today, and from limited seismic observations of the southern extent of the BS within the fold-and-thrust belt, we estimate that the original slide volume was probably originally twice that we have mapped. We estimate, therefore, that the largest single landslide volume for the margin would be $\sim 1000 \mathrm{~km}^{3}$. The Burdwood Slide complex appears to represent a unique series of events in the evolution of the South AmericaScotia plate boundary. It may have formed as a result of large-scale flank collapse of Burdwood Bank during the early stage of collision, rather than remobilized sediment from the continental slope.

\subsection{Erosion and deposition at the Subantarctic Front}

The eastern segment of the northern slope of Burdwood Bank is a fold-and-thrust belt bisected by an erosional moat, with several hundred metres of associated incision (Figure 2C). In the east of the survey area, this moat is clearly evident on the 3D seismic data at around $2100 \mathrm{~m}$ water depth (2800 ms TWT) (Figure 6), shallowing to less than $1500 \mathrm{~m}(2000 \mathrm{~ms})$ in the central survey area, where it becomes choked with sediment. The moat bisects the slope, with a very steep southern scarp slope (up to $30^{\circ}$ ), of up to $600 \mathrm{~m}$ vertical relief, and a shallower northern 
slope with varying amount of incision. Because of the elevated vertical relief and steep angle of the southern scarp slope, there are a number of small-volume submarine landslides within the moat, indicating mass wasting of the southern moat margin. Also associated with the moat are a series of convex-up depositional bodies, typically 10-20 km long (along-slope) and 2-5 km wide (down-slope), and surface areas of 5-50 $\mathrm{km}^{2}$. These bodies have higher seabed amplitudes and greater internal reflectivity than the underlying substrate, and are preferentially deposited in the synclines between active toe thrusts, particularly on the back limb (southern side) of the structures (Figure 6D). They are most common immediately adjacent to the moat, but are also present in synclines further to the north. Because of their characteristic morphology and their association with an active bottom-water current, we interpret these as 'perched' contourite drift deposits. Although they are morphologically similar to the generic 'patch drifts' and 'confined drifts' (Rebesco et al., 2014), their specific depositional context - on stepped and tectonically active intra-slope basins, similar to perched turbidite deposits (Sinclair and Tomasso, 2002) leads us to distinguish them as a separate category of contourite deposit.

We interpret both the erosional (moat) and depositional (perched drifts) features to have formed as a result of active or recent currents associated with the SAF. The moat likely formed due to erosion beneath the high-velocity vertical core of the SAF, which is confined by the continental slope and intersects the seabed at water depths of 1500-2000 m. This is consistent with observations from the Falkland Plateau to the north, where a similar, well-developed, moat separates the South Falkland Slope Drift and Lower Falkland Slope Drift at around a depth of $\sim 1600-1700 \mathrm{~m}$ (Nicholson and Stow, 2019) (Figure 2). The perched drifts are deposited where current velocities likely decrease away from the core of the current, particularly downslope of the core of the current in this location. 
Further to the west, extending westward from the central part of the 3D survey (Figure 7), a much larger convex-up depositional body entirely fills the older moat feature (Figure 6E). This sediment body covers the continental slope between $1300 \mathrm{~m}$ and $400 \mathrm{~m}$ water depth at the shallowest point. This depositional feature is referred to as a 'transported basin' by Lagabrielle et al, (2009), implying that it is a perched basin, entrained and deformed by active tectonics. We now propose this body to be a large plastered contourite drift, deposited where current velocities are lower, up-slope of the main high-velocity core of the SAF $(\sim 1500 \mathrm{~m})$. We refer to this feature as the Burdwood Drift (Figure 7). The western end of the drift transitions into an extensive sediment wave field (Figure 2A). This may have formed because of a convergence of current masses, resulting in a decrease in current velocities, or as a result of cascading SAMW water masses near the convergence zone. We estimate the total volume of sediment in this plastered drift deposit to be around $200 \mathrm{~km}^{3}$, based on an average thickness of $200 \mathrm{~m}$ and an area of around $1000 \mathrm{~km}^{2}$ (Figure 2).

The base of slope to the north of the Burdwood Drift is defined by another slope-parallel moat, with a clear bathymetric expression at water depths of between 1500-1700 m (Figure 7). This erosional feature is at a similar depth to the moat that bisects the slope further to the east, but here forms at the base of the slope due to the westward-shallowing seabed of the Falkland Trough. The combination of base-of-slope erosion and middle-upper slope deposition results in an inherently unstable slope configuration, which is particularly susceptible to failure. The location of this unstable drift deposit coincides with the point source location of submarine landslides identified above (Figure 5). We interpret this association of drift deposition, erosion and landslide generation as strong evidence that the Burdwood Drift is the source of the majority 
of the submarine landslides in the adjacent foredeep, including the three large-volume MTDs above Horizon P.

\subsection{Numerical modelling of submarine landslides and tsunamis}

In this section, we consider the consequences of the submarine landslides identified on the northern slope of Burdwood Bank, using numerical models to determine whether the landslides may have generated significant tsunamis. NHWave and FUNWAVE-TVD model parameters for the base case, and a time-series of model outcomes, are shown in Figure 8. Videos of these models, as well as alternative scenarios for giant- $\left(1000 \mathrm{~km}^{3}\right)$ and small-volume $\left(10 \mathrm{~km}^{3}\right)$ events are available in the Supplementary Materials.

Our base case model for a $100 \mathrm{~km}^{3}$ landslide ( $\sim 1$ million year event) shows that such an event would likely generate an elevated (up to $40 \mathrm{~m}$ wave height) tsunami (Figure 9) on the Falkland Islands $200 \mathrm{~km}$ to the north. If this happened today, there would be major consequences for communities in the region. Our model predicts that, in such a scenario, a $>10 \mathrm{~m}$ wave would hit the town of Stanley in the east of the Falkland Islands around 70 minutes after the landslide failure. The maximum wave height is directly north of the landslide location, due to a combination of the interference effects of the wave front and the interaction of the wave with the shallow bathymetry of the continental shelf of the Falkland Plateau. This would result in significant run-up along the south-facing coast of the Falkland Islands. Assuming an inverselogarithmic relationship between landslide size and frequency, smaller volume $\left(\sim 10 \mathrm{~km}^{3}\right)$ landslides are likely to be much more frequent. Our numerical model shows that these events would likely generate maximum waves of 2-6 $\mathrm{m}$ on the Falkland coast; again representing a significant hazard to local communities. Our worst-case model, representing a 1-in-30 million 
year, flank collapse event, predicts a tsunami with a maximum wave height of $160 \mathrm{~m}$, with the affected area extending across the South Atlantic region.

\section{Discussion}

\subsection{SAF sedimentary conveyor belt}

Our results show that the mapped submarine landslides in the Falkland Trough are derived from the large Burdwood Drift, a plastered contourite drift on the northern slope of Burdwood Bank. Cumulative sediment volumes for the submarine landslides in the Falkland Trough exceed those in the Burdwood Drift, which suggests that the drift has been repeatedly resupplied with sediments by strong currents associated with the SAF. In this section, we consider the source-to-sink processes that explain this, and the influence of the SAF in preconditioning the slope sediments for failure. The large volume $\left(\sim 200 \mathrm{~km}^{3}\right)$ of sediment in the Burdwood Drift, clearly, has not been derived from subaerial erosion of Burdwood Bank, which, at $>100 \mathrm{~m}$ below sea level, would have remained almost entirely submerged during the Last Glacial Maximum and preceding glacial lowstands. Neither could the sediment have been derived from erosion of the moat alone, given a total eroded volume of $<50 \mathrm{~km}^{3}$ for this feature. We propose, therefore, that the sediment is most likely to have been produced by submarine erosion and peneplanation of the $\sim 4000 \mathrm{~km}^{2}$ Burdwood Terrace, located to the south-east of our 3D seismic data (Figure 2 and 10). Current velocities exceeding $30 \mathrm{~cm} / \mathrm{s}$ at the seabed at the core of the SAF (Smith et al., 2010), may be sufficient to erode and entrain fine-grained sediment (Heezen and Hollister, 1964), but these velocities may substantially increase during benthic storms, when mesoscale eddies extend to the seafloor (Smith et al., 2010, Sheen et al., 2012). Current velocities may also vary significantly seasonally, as observed for other deep bottom currents (Miramontes et al., 
2019). Thus, erosion might be semi-continuous, with the majority of erosion, and sediment transport, occurring during episodic benthic storms. In addition, the Burdwood Terrace also sits directly north-west of the 54-54 Passage, where the SAF is constricted by a relatively shallow and narrow seafloor, resulting in enhanced edification in the lee of the passage (Hallberg and Gnanadesikan, 2006).

The Burdwood Terrace is situated at water depths of 1200-2000 m, except where it has been uplifted to a depth of around $1000 \mathrm{~m}$ at its eastern margin (Figure 2C). These water depths are consistent with the core of the SAF (Smith et al., 2010). They are also consistent with the depth of the erosional terrace formed by the SAF on the Falkland Plateau, where erosion exceeds $300 \mathrm{~m}$ (Nicholson and Stow, 2019). The SAF is also likely to have caused substantial seabed erosion on the Burdwood Terrace, where erosion rates may be significantly higher than the Falkland Plateau because of high rates of rock uplift and exhumation at the active, transpressional plate boundary. Although the sparse dataset in this area doesn't allow us to constrain the eroded volume from this area, a conservative estimate of $100 \mathrm{~m}$ averaged over the Burdwood Terrace would be sufficient to supply the sediment for all the large-volume MTDs above Horizon P, as well as the sediment now stored in the Burdwood Drift. This area therefore provides a viable source of sediment for the along-slope sediment routing system of the SAF.

Bottom currents associated with the SAF are also likely responsible for entraining and transporting sediment westward along the northern slope of Burdwood Bank, a distance of $\sim 100$ $200 \mathrm{~km}$. Although there is a lack of bottom-current velocity data in this area, the pronounced moat that bisects the fold-and-thrust belt coincides with the surface location of the SAF, and occurs at the same water depth as that of a similar moat on the Falkland Plateau, which has formed at the high-velocity core of the SAF (Naveira Garabato et al., 2003, Nicholson and Stow, 
2019). The moat is associated with small 'perched drifts', deposited mainly down-slope of the moat, where current velocities presumably decrease away from the core of the current.

Sediment in the Burdwood Drift appears to be accumulating locally because of the presence of a large embayment at a restraining bend of the plate boundary (Figure 2), as well as the presence of the easterly-flowing, subducting, Subantarctic Mode Water (SAMW) (Figure 1), forming a local convergence zone in this area. Converging water masses and a shallowing slope likely promote sediment deposition, particularly upslope of the core of the SAF in the plastered Burdwood Drift deposit. Thus, the interaction of slope morphology and active currents plays a fundamental role in the location and size of the drifts in this location, and therefore the location and size (magnitude) of submarine landslides. In addition, sedimentation rates in this drift are likely to be rapid, which likely plays a critical role in the frequency of landslide events. Assuming a similar accumulation rate for the Burdwood Drift as for the SFSD (around 400 $\mathrm{m} / \mathrm{Ma}$ ) (Weber, 2019), sediment accumulation is likely to be sufficiently rapid to regenerate the drift after each successive failure event (every 1Ma or less).

The timing of onset of sedimentation in the Burdwood Drift is uncertain, but a number of lines of evidence indicate an Early Pliocene date. This is the age of the oldest drift deposits in the SFSD (Weber, 2019), which also formed in association with the SAF. This also coincides with, or slightly precedes, the age of 'Horizon P', which represents the main facies transition in the South Falkland Basin. Above this, sedimentation is dominated by the large-volume MTDs, which are derived from failure of the Burdwood Drift. This Early Pliocene age may represent a significant change in the dynamics of the SAF, possible a reduction in current velocities, or a narrower, more constrained SAF (Nicholson and Stow, 2019), promoting the deposition of finegrained plastered drifts on the upper continental slopes. 
Although our observations show a clear relationship between ocean currents and unstable drift deposition north of Burdwood Bank, more data is required to understand the underlying processes and test the hypotheses developed here. In particular, direct current velocity measurements are required to understand the importance of seasonal and annual variability in SAF dynamics, and the role of eddies in erosion of the continental slope in this region. In addition, more high-resolution seismic data is required, across the Burdwood Terrace in particular, to test the hypothesis that this feature is formed by bottom current erosion, and is the primary source of the sediment accumulating in the Burdwood Drift.

\subsection{Preconditioning mechanisms for slope failure}

The SAF acts as a sedimentary conveyor belt that supplies the material for multiple successive submarine landslides, but it also plays a significant role in preconditioning the slope for failure. The fine-grained nature of the sediment and rapid rate of deposition of the drift may result in the retention of pore fluids and cause a buildup of overpressure from depths as shallow as a few hundred meters below the surface (Flemings et al., 2008), reducing the vertical effective stress and promoting failure. Laterally continuous sand or silt deposits, which are up to $10 \mathrm{~m}$ thick in the SFSD (Nicholson and Stow, 2019), have very low shear strength and, if present in the Burdwood Drift, would further decrease the stability of the slope. Failure is also promoted by the steep, basinward-dipping nature of bedding planes within the drift, and weak sand or silt layers in such a configuration would be particularly prone to failure (Figure 7). We note that the base of the drift (and possible slide scar from an earlier event) also corresponds with a bottom-simulating reflection (Figure 2B), which represents the base of the gas hydrate stability zone. Although still somewhat contentious as a mechanism for triggering submarine landslides (Maslin et al., 2004, 
Lee, 2009), dissociation of hydrates caused by sea-level change or increasing sea-bottom temperatures would also result in a reduction of shear strength, and high concentrations of free gas below the hydrate layer, further increasing the probability of failure. Seismic shaking is likely to be the final triggering mechanism for submarine landslides. $\mathrm{M}_{\mathrm{w}}$ 6-7 earthquakes occur at the plate boundary to the south of the Burdwood Drift, with historic earthquakes of such magnitude within $200 \mathrm{~km}$, and smaller $\left(\mathrm{M}_{\mathrm{w}} 4-6\right)$ historic events clustering around the northern slope of Burdwood Bank, in close proximity to the Burdwood Drift (Figure 1C). However, the frequency of large earthquakes is much higher than that of the submarine landslides, and it is clear that the preconditioning factors play a more important role than seismic shaking in promoting failure (Miramontes et al., 2018a).

\subsection{Tsunami hazards in the Falkland Islands}

Our numerical tsunami models highlight a significant, and previously overlooked, geological hazard that could affect the Falkland Islands, $150 \mathrm{~km}$ to the north of the Burdwood Bank. Although the frequency of large $\left(100 \mathrm{~km}^{3}\right)$ events is likely to be relatively low $(<1 \mathrm{Ma})$, smaller $\left(1-10 \mathrm{~km}^{3}\right)$ events are likely to be much more frequent and may conceivably have affected the islands during the Holocene. Possible tsunami deposits have been described in the Falkland Islands (pebble pavements situated 8-15 m above sea level) (Regnauld et al., 2008), but these are located on the north-facing coastline of West Falkland, an area not at risk from the landslide tsunamis we have identified. No palaeo-tsunami research has been carried out in the south-facing coastline susceptible to inundation from a landslide tsunami generated on Burdwood Bank. Low-lying, nearshore lake systems and thick Late Pleistocene - Holocene peat deposits (Aldiss and Edwards, 1999) near the town of Stanley on East Falkland (Figure 8) 
represent the most suitable sites for such future research. Although only likely to reveal events extending back to the last glacial maximum at most, such an approach has successfully identified palaeo-landslide tsunamis in other settings (Bondevik et al., 2003) and should be an important part of any future effort to constrain the landslide tsunami risk in the Falklands.

Further afield, $400 \mathrm{~km}$ to the west in Tierra del Fuego (Figure 1C) interpreted tsunami deposits (Bujalesky, 2012) remain unexplained in terms of a tsunami-generating mechanism. Although beyond the geographic limits of our FUNWAVE-TVD model, the maximum wave amplitude at the western boundary of our base-case model still exceeds $10 \mathrm{~m}$, thus landslide tsunamis generated from Burdwood Bank may represent a viable mechanism for these deposits. Future models should therefore be extended to include far-field tsunami inundation of other South Atlantic coastlines, as well as the Falkland Islands.

\subsection{Bottom currents in active margin settings}

The oceanographic and tectonic setting of Burdwood Bank are different to other wellresearched regions where there is an association between contourites and submarine landslides. In the case of the Storegga Slide, offshore Norway, the presence of mechanically weak contourite deposits are a major contributory factor to slope failure. However, the Storegga landslide is composed primarily of glacigenic deposits, and it was the rapid loading of these sediments which caused the overpressure in the underlying contourites, resulting in their failure as decollement layer (Bryn et al., 2005). In our case, all the sediment in the submarine landslides are derived from the contourite drift, with the depositional configuration promoting failure. A number of submarine landslides offshore Uruguay and Argentina, near the Brazil-Malvinas convergence zone, are also derived from contourites (Ai et al., 2014). However, in this area only 
the small-volume landslides are associated with contourites, possibly as a result of high rates of sediment supply from onshore, and the dominance of down-slope depositional systems. Contourite drifts in the Corsica Trough have been shown to be more prone to failure than hemipelagic slope sediments, particularly because of undercutting at the base of the slope (Miramontes et al., 2018a), and these have morphological similarities to the Burdwood Drift. However, there are some significant differences, including the presence of ash as a weak layer promoting failure (Miramontes et al., 2018b), and downslope sediment supply from the adjacent landmasses.

In the case of the Burdwood Drift, we have an example of an oceanographic sediment routing system that is entirely starved of down-slope sediment supply, where the currents supply, transport and deposit sediments at an active margin, and leave the slope inherently prone to failure. Such oceanographic preconditioning mechanisms for submarine landslides have not previously been identified in active margin settings, even in areas where strong bottom currents are present. This includes areas such as the Japan trench slope system (Strasser et al., 2013, Tappin et al., 2014) and the eastern slope offshore New Zealand (Collot et al., 2001), where large, potentially tsunamigenic submarine landslides have been recognized but the link to oceanographic processes has not been established. This may be due to the fact that landslides are triggered more regularly in such settings, preventing large drifts accumulating, or because drifts are incorporated into accretionary prisms, making them difficult to identify. In such areas, bottom currents are likely to play an important, but as yet unquantified, role in slope failure.

\section{Conclusions}


The North Scotia Ridge is a convergent plate boundary, with an active submarine foldand-thrust that is affected by strong bottom currents associated with the Subantarctic Front. These currents have resulted in significant submarine erosion of the continental slope of Burdwood Bank, and along-slope sediment transport from the Burdwood Terrace to the large Burdwood Drift in a tectonically controlled slope embayment and convergence zone between currents. This plastered drift deposit on the middle to upper slope is preconditioned for failure by rapid sediment accumulation rates, basinward dipping weak layers and erosion at the core of the current, at the base of the slope. These conditions have resulted in multiple large $\left(100 \mathrm{~km}^{3}\right)$ submarine landslides since the Pliocene, which are likely triggered by large earthquakes at the nearby plate boundary. Numerical modelling of landslide events show that they can generate hazardous tsunamis that pose a risk, previously unrecognized, to the Falkland Islands to the north. This research further highlights the importance of contourite deposition and erosion in submarine landsliding and tsunami generation, and the interaction of tectonic and oceanographic processes in controlling the location, frequency and magnitude of such events.

\section{Acknowledgements}

This work was supported by a Research Incentive Grant (70749) from the Carnegie Institute. We also thank the Falkland Island Government, Borders \& Southern Petroleum and Rockhopper Exploration for providing seismic reflection data and well data for this research. DRT and DMC publish with permission of the CEO, British Geological Survey. DMC acknowledges the continued support of the Department of Mineral Resources, Falkland Island Government. We also acknowledge Phil Stone (BGS) for discussions over possible tsunami deposits on the Falklands during the early stages of this project. 


\section{FIGURE CAPTIONS}

Figure 1. (A) Topographic features, plate tectonic and oceanographic setting of the North Scotia Ridge, showing the locations of the main fronts (jets) of the Antarctic Circumpolar Current, including the Subantarctic Front (SAF), Polar Front (PF) and Southern Antarctic Circumpolar Current Front (SACCF), modified from (Orsi et al., 1995). SAM - South American Plate, SP Scotia Plate, AP - Antarctic Plate, WSR - West Scotia Ridge, SG - South Georgia Island. Image created using GeoMapApp. (B) Current velocity transect across the North Scotia Ridge (location shown in Fig 1A; modified from Smith et al., 2010), from Burdwood Bank in the west to South Georgia Island in the east, showing the location of the 54-54 Passage through which the SAF is focused. SAMW - Subantarctic Mode Water, AAIW - Antarctic Intermediate Water, UCDW Upper Circumpolar Deep Water, LCDW - Lower Circumpolar Deep Water. (C) Seismic and well data available for this study, and focal mechanism solutions for moderate-large ( $\left.M_{w} 5-7\right)$ earthquakes in the region from the CMT database (Ekström et al., 2012), as well as other smaller (>4.0) earthquake locations from the USGS database (accessed 2019). SFB - South Falkland Basin, FT - Falkland Trough.

Figure 2. GEBCO 30-arc second grid bathymetry data across Burdwood Bank, showing the main geomorphological features at the South America-Scotia plate boundary. Contour interval is $100 \mathrm{~m}$. White-dashed line highlights the $1500 \mathrm{~m}$ water depth contour, approximating the intersection of the Subantarctic Front with the continental slope. Dashed black lines numbered 13 show the structural domains of the northern slope of Burdwood Bank referred to in the text. SFSD - South Falkland Slope Drift, LFSD - Lower Falkland Slope Drift (Nicholson and Stow, 
2019). (A-C) Regional 2-D seismic sections across the northern slope of the Burdwood Bank (locations shown on map), including (A) a shallow dipping north-western margin, with large amplitude sediment waves on the upper slope, (B) a steeply dipping central margin with a locally convex-up sedimentary sequence on the mid-slope and (C) a north-eastern margin with an active fold-and-thrust belt on the lower slope, separated from the deformed Burdwood Terrace by a deeply-incised, slope parallel moat at 1500-1700 m water depth. Stratigraphic ages are constrained by the Stebbing-1 well, as well as Darwin-1 (Figure 3) and by correlation with the Malvinas Basin (Figure 4). Intersections with seismic lines in other figures are shown by white arrows. All seismic sections are in two-way travel time (TWT) and have a vertical exaggeration (VE) of $\sim 5$ times, except for the inset on Figure $2 \mathrm{C}(\mathrm{VE} \sim 3)$.

Figure 3. Seismic section from the BSP 3D survey across the Darwin-1 well, showing stratigraphic penetration in the central foreland basin, and the $\sim 1 \mathrm{~km}$ thick Burdwood Slide, entrained within the fold-and-thrust belt to the south of the well location. Inset map shows the location of the seismic line and the likely extent of the Burdwood Slide. Sinistral strike-slip component of deformation is highlighted by A (section moving away from viewer) and $\mathrm{T}$ (section moving towards viewer).

Figure 4. Regional stratigraphic correlation for the South Falkland Basin. (A) Composite seismic section from the Malvinas Basin in the north-west to the South Falkland Basin in the east. Line location is shown on Figure 1. The depth and age of interpreted horizons in the Malvinas Basin are from Baristeas et al., 2013. The key to interpreted horizons are shown in Figure 3.Vertical exaggeration is $\sim 20$ times. (B) Seismic correlation from the South Falkland Slope Drift (SFSD) 
to the South Falkland Basin. Seismic horizons and sequences for the SFSD are from Koenitz et al. (2008); stratigraphic ages are from the U-1534 well (Weber et al., 2019). Line location is shown on Figure 2.

Figure 5. Mass Transport Deposits (MTDs) in the foredeep of the South Falkland Basin. (A) Seismic cross section showing the erosive bases and chaotic internal character of the MTDs. (B) Time thickness (isochron) maps of the three largest recent MTDs in the South Falkland Basin showing the erosive nature of the submarine landslide. Sharp boundaries are caused by erosional scouring at the base of the deposits, both parallel and perpendicular to the flow direction. Kinematic indicators are used to calculate paleoflow directions (white arrows) and to reconstruct the point source (black arrows) for each of the landslides. Black polygon shows the outline of the 3D seismic data. (C) Dip angle map showing kinematic indicators - flow-parallel erosional lineations - at the basal shear surface of MTD 2, which indicate a change in flow direction on either side of a $200 \mathrm{~km}^{2}$ erosional scour, highlighted by the red dashed line. (D) Frozen blocks within MTD2, evident from a surface map of the top of the deposit.

Figure 6. Seafloor depth map (contour interval of $50 \mathrm{~m}$ ) interpreted from 3D seismic, and seismic sections (TWT) showing evidence of along-slope erosion and sediment transport from east to west along the northern margin of Burdwood Bank. The eastern part of the slope is characterized by a deeply incised mid-slope moat and small perched drifts, whereas the western slope is characterized by the presence of a choked mid-slope moat filled by a large plastered drift deposit. 
Figure 7. Composite 2D and 3D seismic section (TWT) across the steep central segment of the Burdwood Bank slope, showing the presence of a plastered slope drift, the Burdwood Drift, on the middle slope between a depth of $600 \mathrm{~m}$ and $1400 \mathrm{~m}$ at this location. The line location is shown on Figure 6. Seismic reflections within the drift are dipping steeply towards the basin in the north. The base of the slope is being actively eroded and undercut by an erosional moat at $\sim 1500 \mathrm{~m}$ water depth (2000 ms TWT) leading to an inherently unstable slope configuration.

Figure 8. Numerical modelling of submarine landslides and consequent waves on the northern slope of Burdwood Bank. (A) Outlines of NHWave and FUNWAVE-TVD models used for the landslide/initial wave and the wave/runup respectively. White star shows the central point of the submarine landslides. (B) Oblique view of Burdwood Bank slope showing the restored sediment volume used to model the base-case landslide in NHWave. (C) Landslide parameters for the base case model. (D-F) initial wave generated by the landslide in NHWave and (E-I) wave propagation and runup modelled in FUNWAVE-TVD. Animations of simulations can be found in the supplementary materials.

Figure 9. Maximum wave heights for the small $\left(10 \mathrm{~km}^{3}\right)$, medium (base case, $\left.100 \mathrm{~km}^{3}\right)$ and maximum $\left(1000 \mathrm{~km}^{3}\right)$ landslide volumes. Note that the scale bar changes for the different model outcomes.

Figure 10 (and visual abstract). Summary of processes for the Subantarctic Front submarine landslide conveyor belt. Wave heights at the Falkland Island coast are derived from the base case $\left(100 \mathrm{~km}^{3}\right)$ model, which is estimated to recur once every $\sim 1$ Ma or less. 


\section{References cited}

The GEBCO_2014 Grid, version 20150318, www.gebco.net

USGS Earthquakes Hazard Programme, https://earthquake.usgs.gov/earthquakes/

AI, F., STRASSER, M., PREU, B., HANEBUTH, T. J., KRASTEL, S. \& KOPF, A. 2014. New constraints on oceanographic vs. seismic control on submarine landslide initiation: a geotechnical approach off Uruguay and northern Argentina. Geo-Marine Letters, 34, 399-417.

ALDISS, D. \& EDWARDS, E. 1999. The geology of the Falkland Islands.

ASSIER-RZADKIEAICZ, S., HEINRICH, P., SABATIER, P., SAVOYE, B. \& BOURILLET, J. 2000. Numerical modelling of a landslide-generated tsunami: the 1979 Nice event. Pure and Applied Geophysics, 157, 1707-1727.

BARISTEAS, N., ANKA, Z., DI PRIMIO, R., RODRIGUEZ, J., MARCHAL, D. \& DOMINGUEZ, F. 2013. New insights into the tectono-stratigraphic evolution of the Malvinas Basin, offshore of the southernmost Argentinean continental margin. Tectonophysics, 604, 280-295.

BIRD, P. 2003. An updated digital model of plate boundaries. Geochemistry, Geophysics, Geosystems, 4.

BLEWITT, G., KREEMER, C., HAMMOND, W. C., PLAG, H. P., STEIN, S. \& OKAL, E. 2006. Rapid determination of earthquake magnitude using GPS for tsunami warning systems. Geophysical Research Letters, 33.

BONDEVIK, S., MANGERUD, J., DAWSON, S., DAWSON, A. \& LOHNE, Ø. 2003. Record-breaking height for 8000-year-old tsunami in the North Atlantic. Eos, Transactions American Geophysical Union, 84, 289-293.

BRY, M., WHITE, N., SINGH, S., ENGLAND, R. \& TROWELL, C. 2004. Anatomy and formation of oblique continental collision: South Falkland basin. Tectonics, 23.

BRYN, P., BERG, K., FORSBERG, C. F., SOLHEIM, A. \& KVALSTAD, T. J. 2005. Explaining the Storegga slide. Marine and Petroleum Geology, 22, 11-19.

BUJALESKY, G. G. 2012. Tsunami overtopping fan and erosive scarps at Atlantic coast of Tierra del Fuego. Journal of Coastal Research, 28, 442-456.

CHERESKIN, T. K., DONOHUE, K. A., WATTS, D. R., TRACEY, K., FIRING, Y. \& CUTTING, A. 2012. cDrake: Dynamics and transport of the Antarctic circumpolar current in drake passage. Oceanography, 25, 134-135.

COLLOT, J. Y., LEWIS, K., LAMARCHE, G. \& LALLEMAND, S. 2001. The giant Ruatoria debris avalanche on the northern Hikurangi margin, New Zealand: Result of oblique seamount subduction. Journal of Geophysical Research: Solid Earth, 106, 19271-19297.

EAGLES, G. \& JOKAT, W. 2014. Tectonic reconstructions for paleobathymetry in Drake Passage. Tectonophysics, 611, 28-50.

EAGLES, G., LIVERMORE, R. A., FAIRHEAD, J. D. \& MORRIS, P. 2005. Tectonic evolution of the west Scotia Sea. Journal of Geophysical Research: Solid Earth, 110. 
EKSTRÖM, G., NETTLES, M. \& DZIEWOŃSKI, A. 2012. The global CMT project 20042010: Centroid-moment tensors for 13,017 earthquakes. Physics of the Earth and Planetary Interiors, 200, 1-9.

ENET, F. \& GRILLI, S. T. 2007. Experimental study of tsunami generation by threedimensional rigid underwater landslides. Journal of waterway, port, coastal, and ocean engineering, 133, 442-454.

FINE, I., RABINOVICH, A., BORNHOLD, B., THOMSON, R. \& KULIKOV, E. 2005. The Grand Banks landslide-generated tsunami of November 18, 1929: preliminary analysis and numerical modeling. Marine Geology, 215, 45-57.

FLEMINGS, P., LONG, H., DUGAN, B., GERMAINE, J., JOHN, C., BEHRMANN, J., SAWYER, D. \& EXPEDITION, I. 2008. Pore pressure penetrometers document high overpressure near the seafloor where multiple submarine landslides have occurred on the continental slope, offshore Louisiana, Gulf of Mexico. Earth and Planetary Science Letters, 269, 309-325.

GALEAZZI, J. S. 1998. Structural and stratigraphic evolution of the western Malvinas Basin, Argentina. AAPG bulletin, 82, 596-636.

GEIST, E. L., TITOV, V. V., ARCAS, D., POLLITZ, F. F. \& BILEK, S. L. 2007. Implications of the 26 December 2004 Sumatra-Andaman earthquake on tsunami forecast and assessment models for great subduction-zone earthquakes. Bulletin of the Seismological Society of America, 97, S249-S270.

HALLBERG, R. \& GNANADESIKAN, A. 2006. The role of eddies in determining the structure and response of the wind-driven Southern Hemisphere overturning: Results from the Modeling Eddies in the Southern Ocean (MESO) project. Journal of Physical Oceanography, 36, 2232-2252.

HARBITZ, C. B., LØVHOLT, F., PEDERSEN, G. \& MASSON, D. G. 2006. Mechanisms of tsunami generation by submarine landslides: a short review. Norwegian Journal of Geology/Norsk Geologisk Forening, 86.

HEEZEN, B. C. \& HOLLISTER, C. 1964. Deep-sea current evidence from abyssal sediments. Marine Geology, 1, 141-174.

HEIDARZADEH, M., MUHARI, A. \& WIJANARTO, A. B. 2019. Insights on the Source of the 28 September 2018 Sulawesi Tsunami, Indonesia Based on Spectral Analyses and Numerical Simulations. Pure and Applied Geophysics, 176, 25-43.

HORNBACH, M. J., BRAUDY, N., BRIGGS, R. W., CORMIER, M.-H., DAVIS, M. B., DIEBOLD, J. B., DIEUDONNE, N., DOUILLY, R., FROHLICH, C., GULICK, S. P. S., JOHNSON III, H. E., MANN, P., MCHUGH, C., RYAN-MISHKIN, K., PRENTICE, C. S., SEEBER, L., SORLIEN, C. C., STECKLER, M. S., SYMITHE, S. J., TAYLOR, F. W. \& TEMPLETON, J. 2010. High tsunami frequency as a result of combined strike-slip faulting and coastal landslides. Nature Geoscience, 3, 783.

KIRBY, J. T., SHI, F., TEHRANIRAD, B., HARRIS, J. C. \& GRILLI, S. T. 2013. Dispersive tsunami waves in the ocean: Model equations and sensitivity to dispersion and Coriolis effects. Ocean Modelling, 62, 39-55.

KOENITZ, D., WHITE, N., MCCAVE, I. N. \& HOBBS, R. 2008. Internal structure of a contourite drift generated by the Antarctic Circumpolar Current. Geochemistry, Geophysics, Geosystems, 9.

KVALSTAD, T. J., ANDRESEN, L., FORSBERG, C. F., BERG, K., BRYN, P. \& WANGEN, M. 2005. The Storegga slide: evaluation of triggering sources and slide mechanics. 
Ormen Lange-an Integrated Study for Safe Field Development in the Storegga Submarine Area. Elsevier.

LAGABRIELLE, Y., GODDÉRIS, Y., DONNADIEU, Y., MALAVIEILLE, J. \& SUAREZ, M. 2009. The tectonic history of Drake Passage and its possible impacts on global climate. Earth and Planetary Science Letters, 279, 197-211.

LEE, H. J. 2009. Timing of occurrence of large submarine landslides on the Atlantic Ocean margin. Marine Geology, 264, 53-64.

MA, G., SHI, F. \& KIRBY, J. T. 2012. Shock-capturing non-hydrostatic model for fully dispersive surface wave processes. Ocean Modelling, 43-44, 22-35.

MASLIN, M., OWEN, M., DAY, S. \& LONG, D. 2004. Linking continental-slope failures and climate change: Testing the clathrate gun hypothesis. Geology, 32, 53-56.

MASSON, D., HARBITZ, C., WYNN, R., PEDERSEN, G. \& LØVHOLT, F. 2006. Submarine landslides: processes, triggers and hazard prediction. Philosophical Transactions of the Royal Society A: Mathematical, Physical and Engineering Sciences, 364, 2009-2039.

MIRAMONTES, E., GARREAU, P., CAILLAUD, M., JOUET, G., PELLEN, R., HERNÁNDEZ-MOLINA, F. J., CLARE, M. A. \& CATTANEO, A. 2019. Contourite distribution and bottom currents in the NW Mediterranean Sea: Coupling seafloor geomorphology and hydrodynamic modelling. Geomorphology, 333, 43-60.

MIRAMONTES, E., GARZIGLIA, S., SULTAN, N., JOUET, G. \& CATTANEO, A. 2018 a. Morphological control of slope instability in contourites: a geotechnical approach. Landslides, 15, 1085-1095.

MIRAMONTES, E., SULTAN, N., GARZIGLIA, S., JOUET, G., PELLETER, E. \& CATTANEO, A. 2018b. Altered volcanic deposits as basal failure surfaces of submarine landslides. Geology, 46, 663-666.

MOSCARDELLI, L. \& WOOD, L. 2016. Morphometry of mass-transport deposits as a predictive tool. Bulletin, 128, 47-80.

NAVEIRA GARABATO, A. C., STEVENS, D. P. \& HEYWOOD, K. J. 2003. Water mass conversion, fluxes, and mixing in the Scotia Sea diagnosed by an inverse model. Journal of physical oceanography, 33, 2565-2587.

NICHOLSON, U. \& STOW, D. 2019. Erosion and deposition beneath the Subantarctic Front since the Early Oligocene. Scientific Reports, 9, 9296.

O'LEARY, D. W. 1991. Structure and morphology of submarine slab slides: clues to origin and behavior. Marine Georesources \& Geotechnology, 10, 53-69.

ORSI, A. H., WHITWORTH III, T. \& NOWLIN JR, W. D. 1995. On the meridional extent and fronts of the Antarctic Circumpolar Current. Deep Sea Research Part I: Oceanographic Research Papers, 42, 641-673.

PELAYO, A. M. \& WIENS, D. A. 1989. Seismotectonics and relative plate motions in the Scotia Sea region. Journal of Geophysical Research: Solid Earth, 94, 7293-7320.

PIOLA, A. R. \& GORDON, A. L. 1989. Intermediate waters in the southwest South Atlantic. Deep Sea Research Part A. Oceanographic Research Papers, 36, 1-16.

PRIOR, D. B. \& COLEMAN, J. M. 1982. Active slides and flows in underconsolidated marine sediments on the slopes of the Mississippi Delta. Marine slides and other mass movements. Springer.

REGNAULD, H., PLANCHON, O. \& GOFF, J. 2008. Relative roles of structure, climate, and of a tsunami event on coastal evolution of the Falkland Archipelago. Géomorphologie: relief, processus, environnement, 14, 34-44. 
SATAKE, K. \& ATWATER, B. F. 2007. Long-term perspectives on giant earthquakes and tsunamis at subduction zones. Annu. Rev. Earth Planet. Sci., 35, 349-374.

SHEEN, K., WHITE, N., CAULFIELD, C. \& HOBBS, R. 2012. Seismic imaging of a large horizontal vortex at abyssal depths beneath the Sub-Antarctic Front. Nature Geoscience, $5,542$.

SHI, F., KIRBY, J. T., HARRIS, J. C., GEIMAN, J. D. \& GRILLI, S. T. 2012. A high-order adaptive time-stepping TVD solver for Boussinesq modeling of breaking waves and coastal inundation. Ocean Modelling, 43, 36-51.

SINCLAIR, H. \& TOMASSO, M. 2002. Depositional evolution of confined turbidite basins. Journal of Sedimentary Research, 72, 451-456.

SMITH, I. J., STEVENS, D. P., HEYWOOD, K. J. \& MEREDITH, M. P. 2010. The flow of the Antarctic Circumpolar Current over the North Scotia Ridge. Deep Sea Research Part I: Oceanographic Research Papers, 57, 14-28.

SOLHEIM, A., BERG, K., FORSBERG, C. \& BRYN, P. 2005. The Storegga Slide complex: repetitive large scale sliding with similar cause and development. Marine and Petroleum Geology, 22, 97-107.

STRASSER, M., KÖLLING, M., FERREIRA, C. D. S., FINK, H. G., FUJIWARA, T., HENKEL, S., IKEHARA, K., KANAMATSU, T., KAWAMURA, K. \& KODAIRA, S. 2013. A slump in the trench: Tracking the impact of the 2011 Tohoku-Oki earthquake. Geology, 41, 935-938.

SULTAN, N., COCHONAT, P., FOUCHER, J.-P. \& MIENERT, J. 2004. Effect of gas hydrates melting on seafloor slope instability. Marine geology, 213, 379-401.

TAPPIN, D. R., GRILLI, S. T., HARRIS, J. C., GELLER, R. J., MASTERLARK, T., KIRBY, J. T., SHI, F., MA, G., THINGBAIJAM, K. \& MAI, P. M. 2014. Did a submarine landslide contribute to the 2011 Tohoku tsunami? Marine Geology, 357, 344-361.

TAPPIN, D. R., MATSUMOTO, T., WATTS, P., SATAKE, K., MCMURTRY, G. M., MATSUYAMA, M., LAFOY, Y., TSUJI, Y., KANAMATSU, T. \& LUS, W. 1999. Sediment slump likely caused 1998 Papua New Guinea tsunami. Eos, Transactions American Geophysical Union, 80, 329-340.

TEHRANIRAD, B., SHI, F., KIRBY, J. T., HARRIS, J. C. \& GRILLI, S. 2011. Tsunami benchmark results for fully nonlinear Boussinesq wave model FUNWAVE-TVD, Version 1.0. Center for Applied Coastal Research, University of Delaware, Tech. Rep.

WARD, S. N. 2001. Landslide tsunami. Journal of Geophysical Research: Solid Earth, 106, 11201-11215.

WEBER, M. E. R., M.E.; PECK, V.L.; WILLIAMS, T.; AND THE EXPEDITION 382 SCIENTISTS 2019. Expedition 382 Preliminary Report: Iceberg Alley and Subantarctic Ice and Ocean Dynamics. International Ocean Discovery Program. 
There is no conflict of interest 
Highlights

- Multiple large submarine landslides identified on northern slope of Burdwood Bank

- Landslides supplied by current erosion and deposition at the Subantarctic Front

- Currents directly control the location, magnitude and frequency of all landslides

- Numerical models indicate major tsunamis, with up to $40 \mathrm{~m}$ wave heights, occur every 1 million years or less 


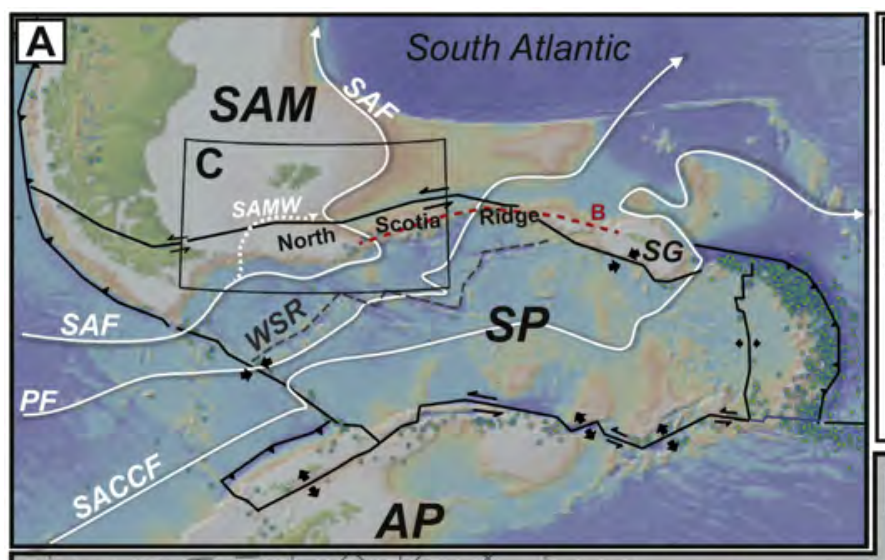

C

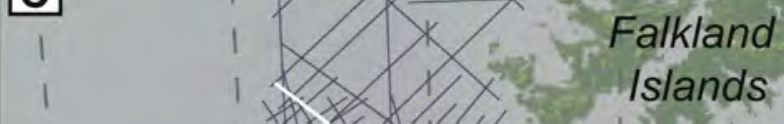

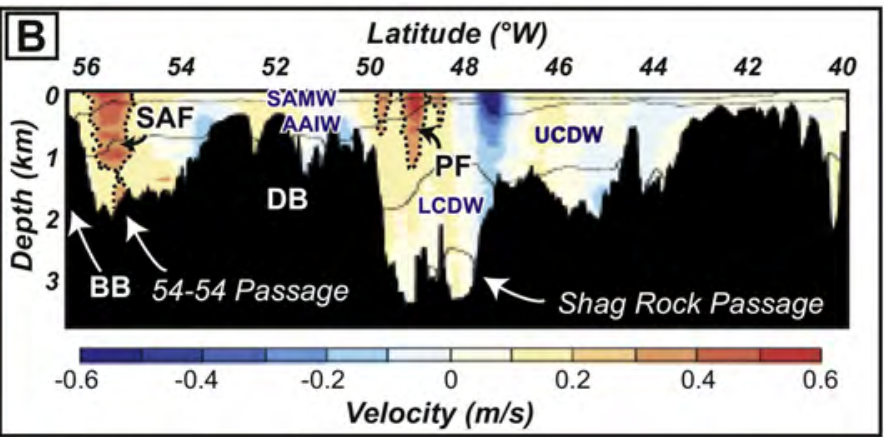
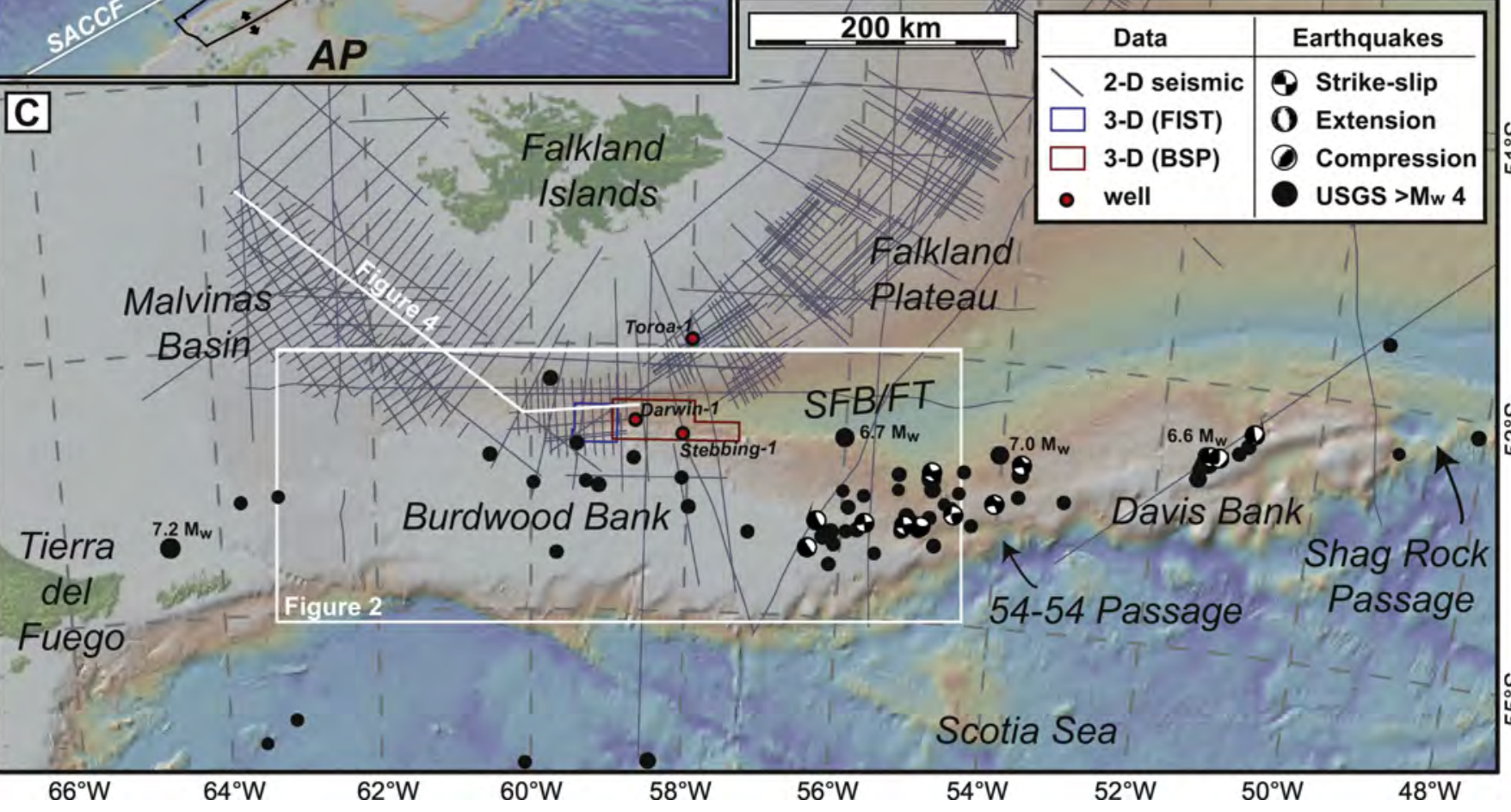


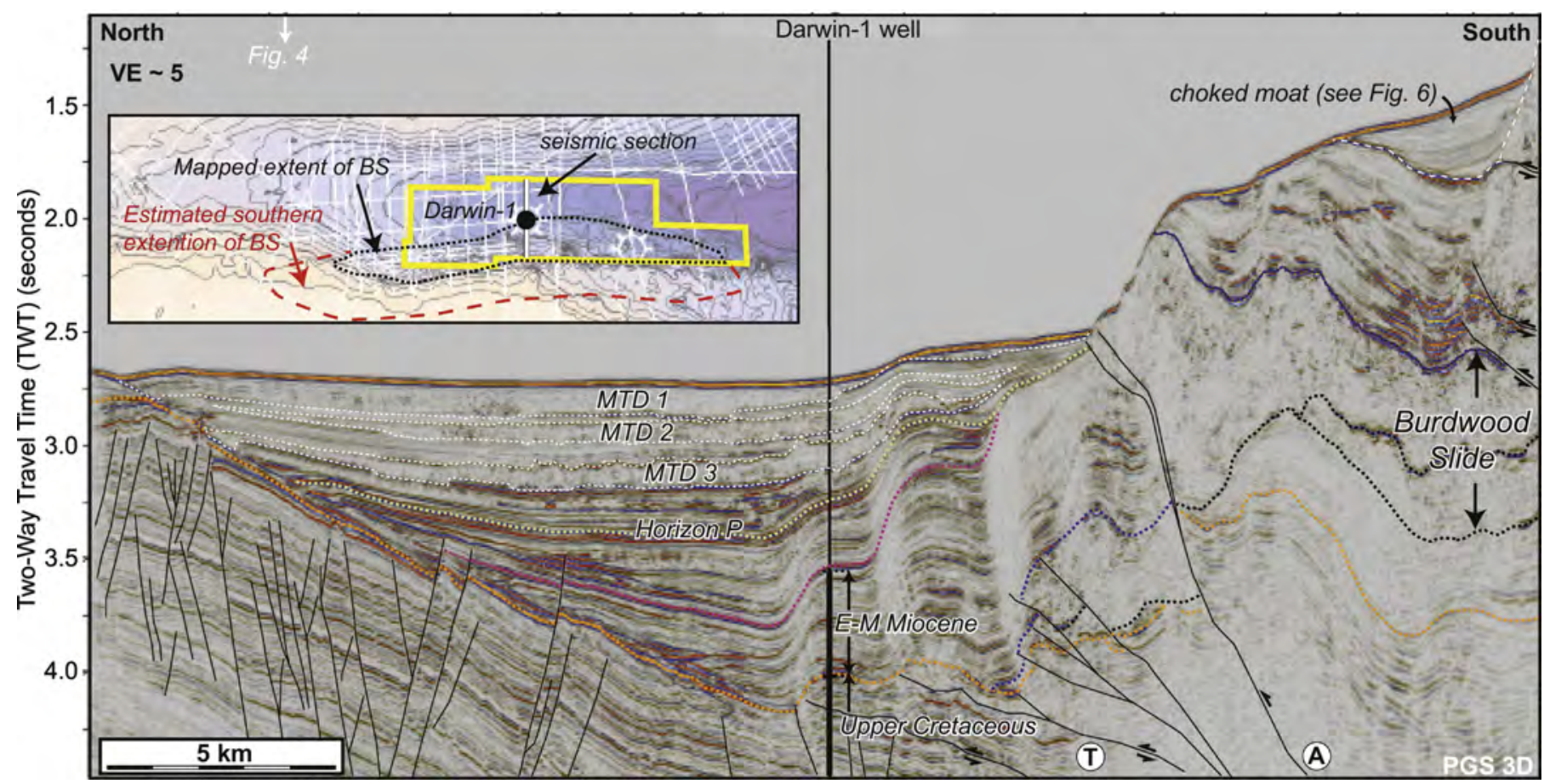

Figure 3 

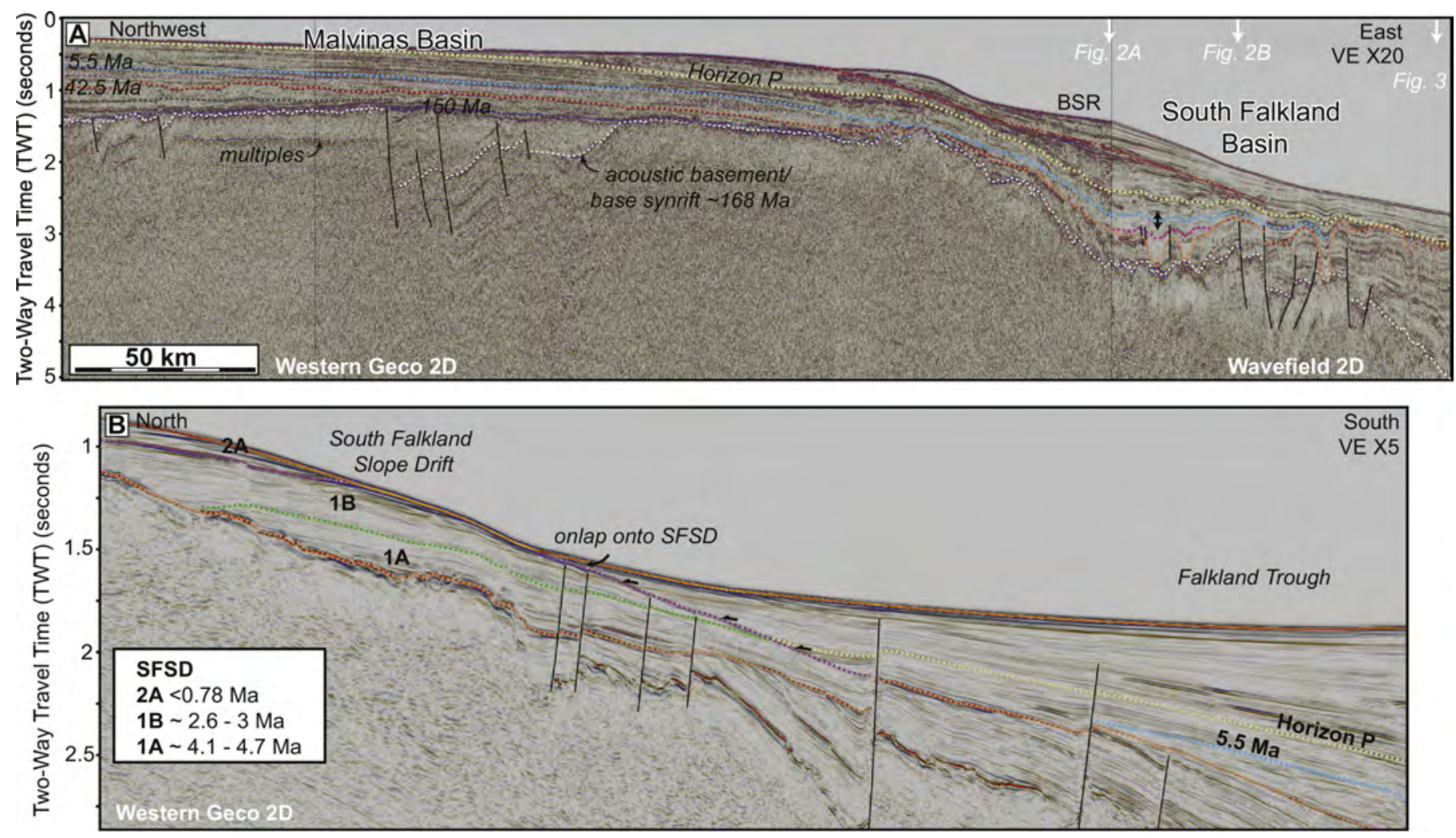

Figure 4 


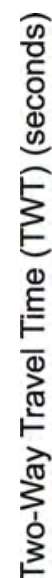

$2.5 \mathrm{~km}$

(MTD1:

B.

MTD 3
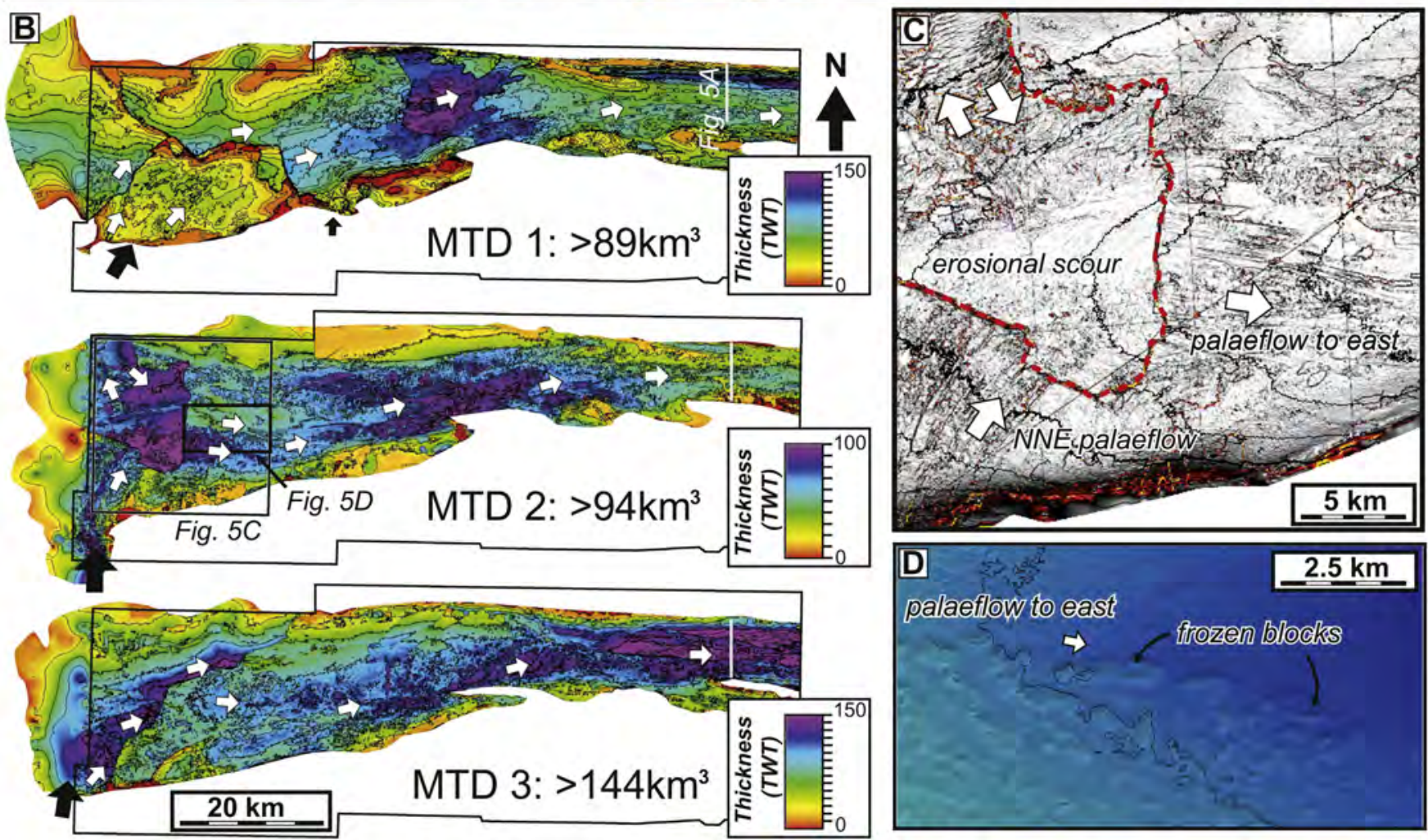

palaeflow to east

$\Rightarrow$

- frozen blocks

Figure 5 


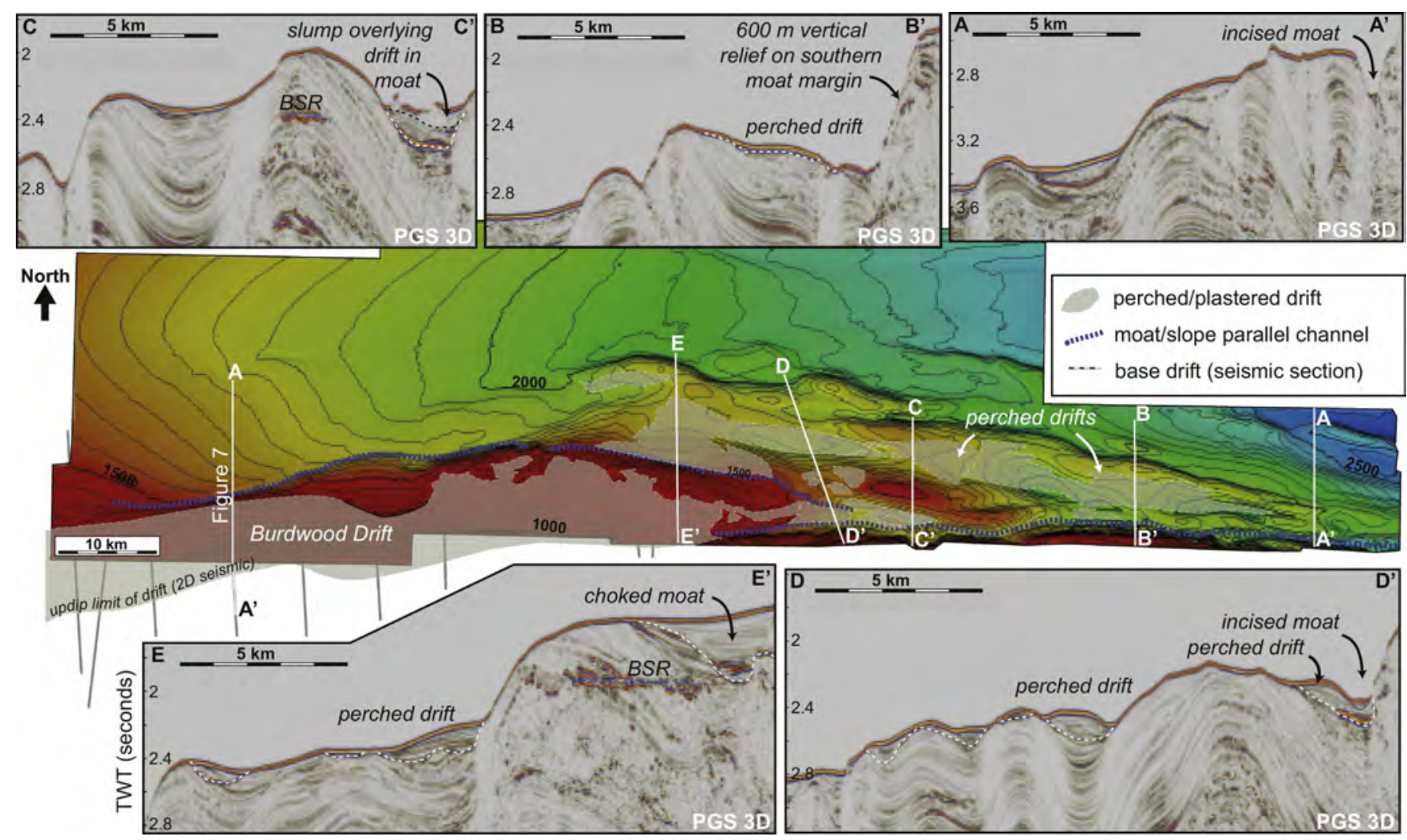

Figure 6 


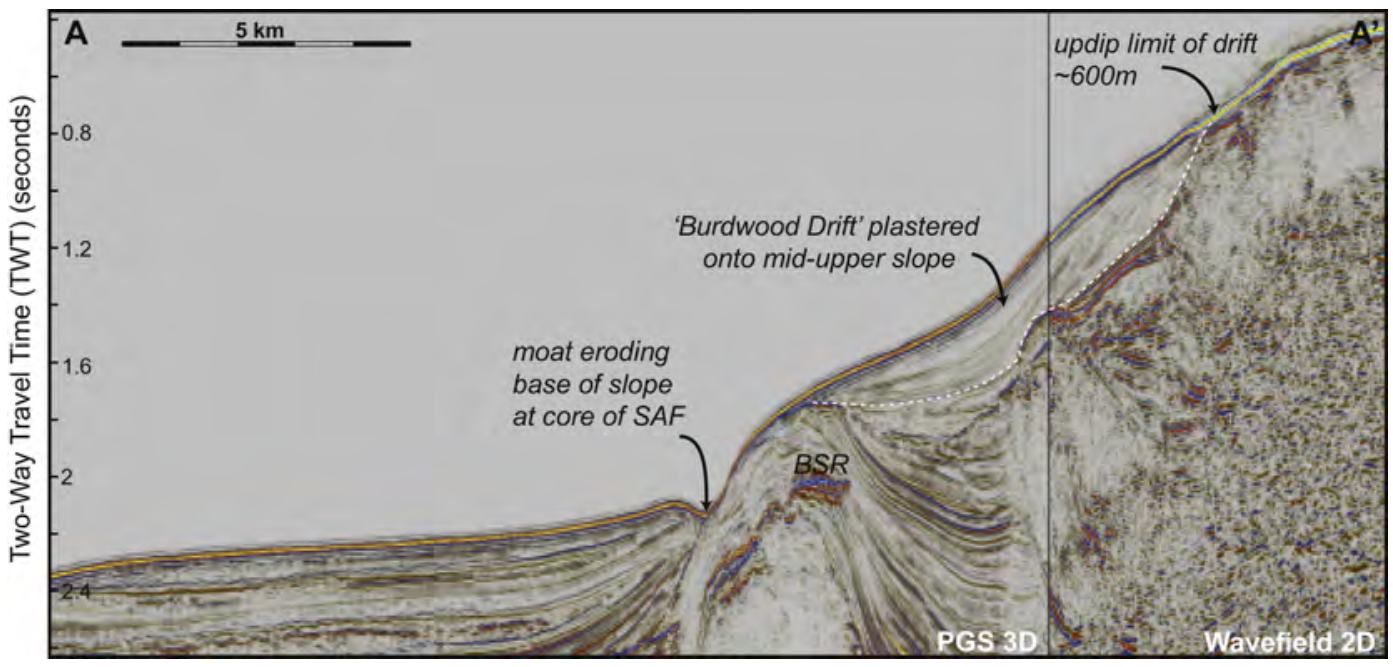

Figure 7 


\section{A}

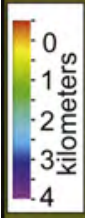
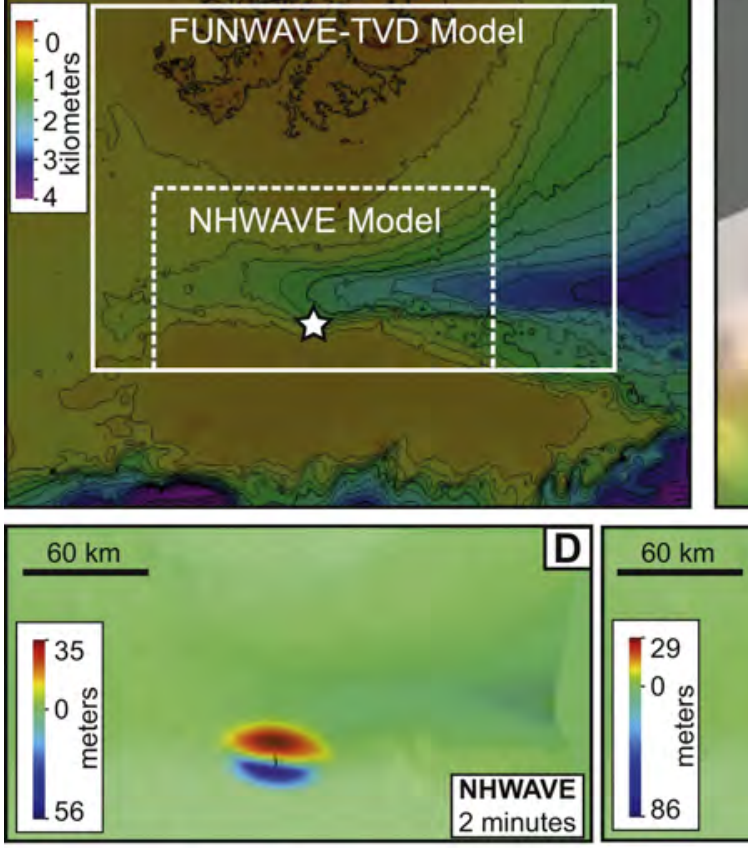

$B$

C Landslide parameters (base case) Max width $(\mathrm{km})$

Max length $(\mathrm{km})$

Max thickness (m)

Volume $\left(\mathrm{km}^{3}\right)$

Initiation depth $(\mathrm{m})$

Slope angle $\left({ }^{\circ}\right)$

Initial acceleration $\left(\mathrm{m} / \mathrm{s}^{2}\right)$

Max velocity $(\mathrm{m} / \mathrm{s}$ )

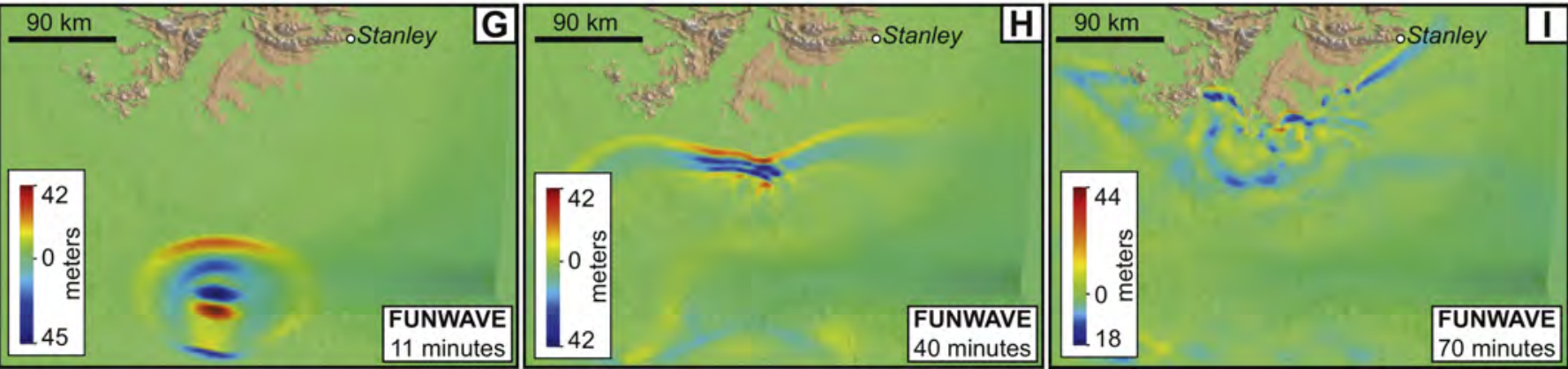

Figure 8 


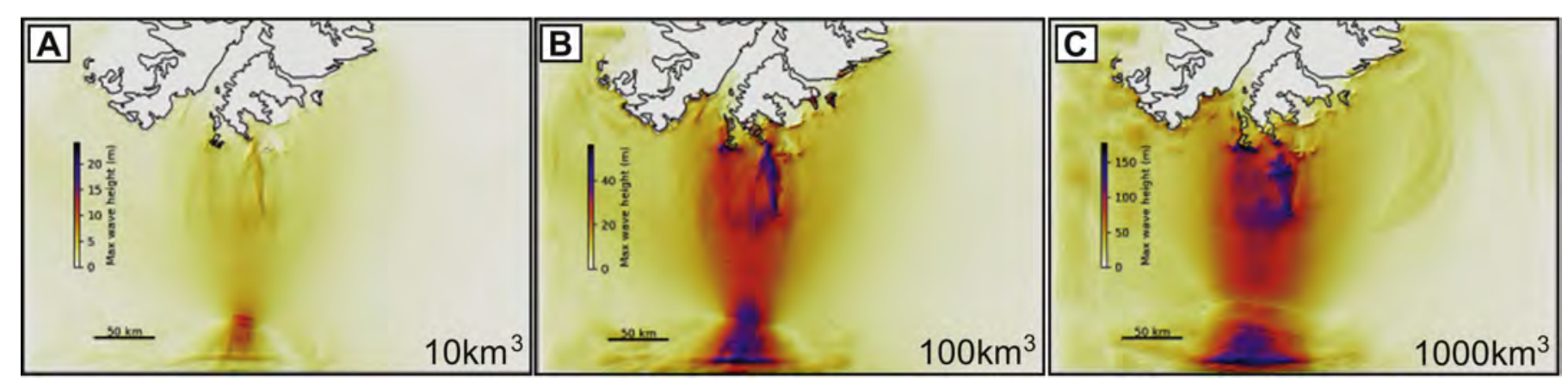

Figure 9 


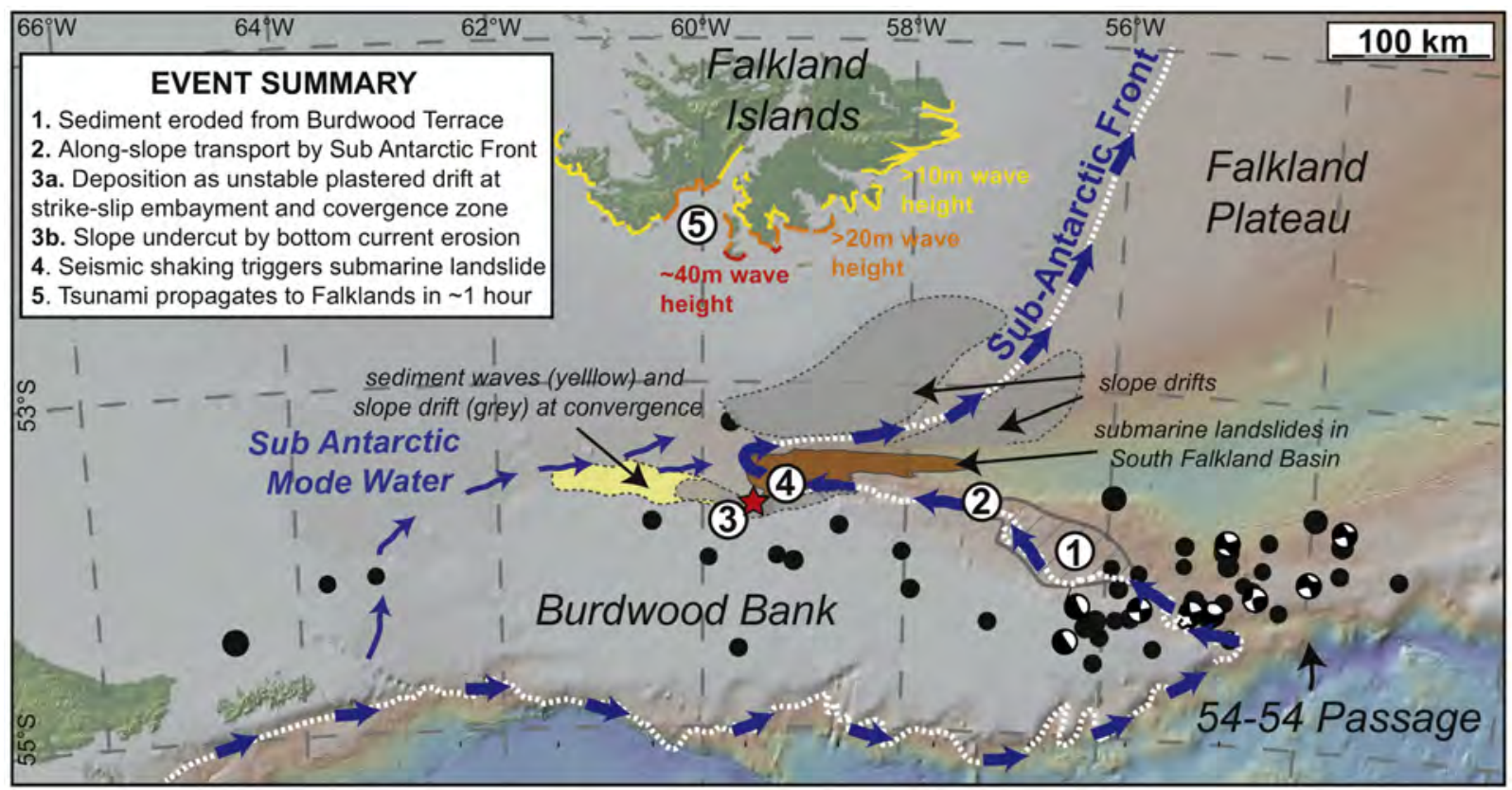

Figure 10 